Hristo Saldzhiev (Stara Zagora)

(iD) https://orcid.org/0000-0002-4116-6600

\title{
Continuity between Early Paulicianism and the Seventeenth-Century Bulgarian Paulicians: the Paulician Legend of Rome and the Ritual OF THE BAPTISM BY Fire
}

\begin{abstract}
$\mathrm{D}$ uring the Middle Ages two dualistic communities were active in Bulgaria and Bulgarian lands - Bogomils and Paulicians. Paulicians, unlike Bogomils, survived as a separate religious sect up to the $17^{\text {th }}$ century, when most of them gradually accepted Catholicism. The detailed reports of the Catholic missionaries, priests and bishops shed light on different aspects of their beliefs and practices from the $17^{\text {th }}$ century. The aim of this article is to propose an explanation of a strange ritual and legend spread among the Bulgarian Paulicans and recorded in the above mentioned reports. The premise of the article is that the legend and ritual in question refer to the early history of Paulicianism. The ritual is related to syncretic religious notions and goes beyond the scope of dualism. I will try to examine the legend and ritual in the context of their history in the Balkans, especially in the context of their belief system, inherited from the early Anatolian Paulicians.
\end{abstract}

\section{Sources of investigations}

The sources used in the article include works and reports written in Greek, Old Slavonic, Armenian and Latin, composed in the long period between the $9^{\text {th }}$ and $17^{\text {th }}$ century. The most important of them are:

- The works of Euthymius Zigabenus and Petrus Siculus - both written in Greek. The first contains a chapter about Paulicians. It is based on the evidence taken from the works of St. Photius. The second was written by the Byzantine diplomat Petrus Siculus, who visited the Paulician "capital" Tephrice around 870-871 AD. In spite of criticism by some authors, who maintain that both works are later compilations composed during the reign of Constantine VII 
Porphyrogenitus 945-959 $\mathrm{AD}^{1}$, there are strong arguments indicating that some pieces of evidence these works provide about the Paulician doctrine and practices are closely related and probably are the prototypes of some beliefs registered by Catholic missionaries among Bulgarian Paulicans in the $17^{\text {th }}$ century.

- John Exarch's work - Shestodnev, containing information about the earliest dualistic notions spread in Bulgarian lands at the beginning of the $10^{\text {th }}$ century.

- Reports about Paulicians and their beliefs and customs, written by Catholic bishops and missionaries in the $17^{\text {th }}$ century.

- A medieval Armenian legend concerning the origins and beliefs of Paulicians. It was discovered by Armenian researchers and subsequently published in the Bulgarian historian Donka Radeva’s work on Paulicianism.

\section{Early Paulicianism - religious notions}

The early history of Paulicianism usually is sought in the $7^{\text {th }}$ century Anatolia, but many aspects of this history are unclear and disputable. The linguistic analysis of the name "Paulicians" contributes to further complexity of the problem of their origin - it indicates the Armenian adoption of Middle Persian or Parthian derivative of the personal name "Paul"2. According to Seta Dadoyan, Paulicians were mentioned for first time in the documents issued by the Council of Armenian bishops, which took place in Dvine in 554-555 AD. Then the Paulicians were considered to belong to the so-called Mẹghnean, condemned by the council, but this note could be a later addition. However, the same term was used by the Armenian Catholicos Hovhan of Ohzun to designate $8^{\text {th }}$ century Paulicians ${ }^{3}$. The designation Mẹzghnean covered heretical groups sharing the Pythagorean doctrine and known also as Vegetarians and Sun Worshippers. It seems that there were some doctrinal similarities with Marcionites and Manicheans - all of these groups rejected the resurrection of bodies and marriage ${ }^{4}$.

Byzantine narratives about the first religious leaders of Paulicians seem to convey mostly legends rather than facts. The connection with Manicheism on which the Byzantine authors insist was probably real but it seems exaggerated. This new "Manicheism" knew nothing about Mani, but as we can see below, it must have been directly affected by the ideas of Marcionism. Paulicians were noticed by

\footnotetext{
${ }^{1}$ N. GarsoÏAn, The Paulician Heresy. A Study of the Origins and Development of Paulicianism in Armenia and the Eastern Provinces of the Byzantine Empire, The Hague 1967, p. 77.

${ }^{2}$ А. Периханян, К вопросу О Происхождении Павликианства, ППВ 2, 2011, p. 67-68.

${ }^{3}$ S. Dadoyan, The Fatimid Armenians. Cultural and Political Interaction in the Near East, Leiden 1997, p. 31-32.

${ }^{4}$ Ibidem, p. 27-28.
} 
historians in mid- $9^{\text {th }}$ century, when they seized the mountain fortress Tephrice in the eastern part of Anatolia and formed their short-lived quasi-state, which engaged in constant wars with Byzantine. From that moment on they attracted constant attention of Byzantine authors. In that period and for a long time after the fall of Tephrice and the collapse of their state, they were a typical example of a militarized religious sect led by military commanders.

Drawing on evidence provided by Petrus Siculus and Euthymius Zigabenus, I will try to present their beliefs in comparative context, seeking parallels to previous heretical teachings.

- Parallels to Marcionism:

- Existence of two gods - the god of good and the god of evil. The second is comprehended as a creator and lord of the present world, and the first as god of the future world ${ }^{6}$. This kind of dualism some researchers called "absolute", in contrast with the dualism of Bulgarian Bogomils, who preached that the visible word was created by Satan (an angel created by God), who initiated a revolt against God and became the leader of the fallen angels. This dualism, according to which evil has secondary character, is defined as "moderate".

- Rejection of the entire Old Testament and the Prophets ${ }^{8}$.

- Rejection of St. Peter the Apostle and reducing the canonic books of the New Testament - the epistles of St. Peter were excluded from the New Testament books used by Paulicians ${ }^{9}$.

- Legitimation of their communities by means of the missionary activity of St. Paul the Apostle. The latter becomes visible from their practice to name their communities and leaders after the churches established by St. Paul and after his disciples (see below). A medieval Bulgarian legend concerning the origin of Bulgarian Paulicians, notices that These people are called Paulicians and they glorify Paul ${ }^{10}$. Even in the $17^{\text {th }}$ century this respect

\footnotetext{
${ }^{5}$ The late archimandrite Pavel Stefanov, Bulgarian researcher of Gnosticism, also insisted on the connections of Paulicianism with Marcionism but did not regarded this problem in detail in his work on the gnostic teachings: П. СтЕфАнов, Ялдаваот. История и учение на гностическата религия, София 2008, p. 177.

${ }^{6}$ Petri Siculi Historia Manichaeorum seu Paulicianorum, Gottingae 1846 (cetera: Petrus Siculus, Historia), p. 11-12.

${ }^{7}$ Д. Ангелов, Богомилството, София 1993, p. 139-140.

${ }^{8}$ Petrus Siculus, Historia, p. 13.

${ }^{9}$ Petrus Siculus, Historia, p. 14.

${ }^{10}$ Слово как се появиха павликяните, [in:] Д. РАдевА, Павликяни и павликянство в българските земи. Архетип и повторения VII-XVII век, София 2015, p. 518.
} 
to St. Paul was mentioned by the English diplomat Paul Rycaut as a distinctive feature of the religious beliefs and practices of the Bulgarian Paulicians before their conversion to Catholicism ${ }^{11}$.

- The notion of the ostensible birth of Jesus Christ. Paulicians do not recognize Virgin Mary as Theotokos and even as virgin because according to them, Jesus was not born in a human body, but He took His body from Heaven ${ }^{12}$.

All of these aspects of the Paulician cult are rooted in the dualistic doctrine of Marcion. He was the first to condemn the books of the Old Testament and its prophets as inspired by the Creator of the present world. Marcion also reduced the books of the New Testament, emphasizing exclusively on the Gospel of Luka and part of the epistles of St. Paul the Apostle. It seems that the exclusive respect to this apostle also originates from Marcion's doctrine. According to Marcion St. Paul the Apostle received exclusive by its nature revelation that revealed him the essence of Jesus' sacrifice ${ }^{13}$. Marcionism survived in various places in the Middle East and Anatolia up to the $7^{\text {th }}$ century ${ }^{14}$.

- Parallels to Montanism and Manicheism: The information provided by Petrus Siculus that the leader of the Paulicians, Sergius, presented himself as the Paraclete $^{15}$ indicates direct influence from Manicheism and indirect from Montanism, a charismatic movement which emerged in Anatolia in the $2^{\text {nd }}$ century ${ }^{16}$ and whose followers while in ecstasy pronounced different prophecies. They asserted that these prophecies came from the Holy Spirit and regarded them as a new revelation equal to the revelation of the Bible. According to Montanists, this marked the appearance of a new religious epoch, the one of the Holy Spirit - Paraclete ${ }^{17}$. The last manifestations of Montanism are from the $8^{\text {th }}$ century ${ }^{18}$. Sources say nothing about the existence of a prophetical tradition among Paulicians, but the fact that Sergius declared himself the Paraclete indicates that among Paulicians expectations of Montanistic origin really existed.

\footnotetext{
${ }^{11}$ П. Рико, Сегашното състояние на Османската империя и на гръиката иърква (XVII век), trans. et ed. М. Киселинчева, София 1988, р. 175.

12 Petrus Siculus, Historia, p. 12.

${ }^{13}$ В. Болотов, Лекции по истории Древней Церкви, vol. II, История иеркви в период до Константина Великого, Москва 1994, р. 230.

${ }^{14}$ Ibidem.

${ }^{15}$ Petrus Siculus, Historia, p. 40, 46.

${ }^{16}$ В. Болотов, Лекции ..., р. 351-352.

${ }^{17}$ Ibidem, p. 357-360.

${ }^{18}$ Ibidem, p. 353.
} 
On the other hand, the idea of the Paraclete is widely used in Manicheism, whose founder, Mani, also considered himself the Paraclete ${ }^{19}$.

Another type of Manicheist heritage is the peculiar Prayers - conjurations that Paulicians from Tephrike said before eating bread. Petrus Siculus interprets them as curses against farmers and bakers. According to him, by means of these "prayers" Paulicians declined all responsibility for the "suffering" of the corn and cast the whole blame for this "pain" on farmers and bakers ${ }^{20}$. The roots of this behavior and notions must be sought in the close contacts and interaction of Manicheism with some of the branches of Buddhism.

- Original elements in Paulician practices and doctrines

- Paulician leaders adopted new names which copied the names of the followers of St. Apostle Paul ${ }^{21}$.

- Paulicians named their communities after the names of the churches established by St. Apostle Paul or after the names of the places visited by him ${ }^{22}$.

- Rejection of the Holy Cross ${ }^{23}$ and icons. There are not explicit evidences in the medieval works that Paulicians rejected icons but the Catholic missioners who converted most of the Bulgarian Paulicians to Catholicism in the $17^{\text {th }}$ century mention this specific of their religious ideology ${ }^{24}$. According to me there is no doubt that the rejection of icons was inherited from the medieval past of the sect. For example Bogomils also rejected the Holy Cross and icons. In this case possible influence exerted by Islam or the Byzantine Iconoclasm might be noted. The close contacts of Paulicians with Arabs also give reasons for this hypothesis. However, in my opinion, it is a natural consequence of the dualistic teaching condemning all matter as evil or created by an evil demiurge. The same views in respect to the Holy Cross and icons were maintained by Bogomils, who differed from Paulicians in many other aspects.

\footnotetext{
${ }^{19}$ М. ТАрдио, Манихейството, София 2001, p. 22. Translation from French: M. TARdieu, Le manichéism, Paris 1997.

${ }^{20}$ Petrus Siculus, Historia, p. 23-24.

${ }^{21}$ Petrus Siculus, Historia, p. 48-49.

${ }^{22}$ Petrus Siculus, Historia, p. 48-49.

${ }^{23}$ Petrus Siculus, Historia, p. 15.

${ }^{24}$ Петър Солинат, Доклад на собийския епископ Петьр Солинат до съборната конгрегация в Рим от 1622 2., [in:] Б. Примов, П. САРИЙСКИ, М. Йовков, Документи за католическата дейност в България през XVII век, София 1993 (cetera: Петър СолинАт, Доклад), p. 22.
} 
- Rejection of the Holy Communion: the communion during the Lord's Supper is perceived by Paulicians as His sermon, symbolized by wine and bread $^{25}$.

- Rejection of the Orthodox church: it is accused of opposition to God ${ }^{26}$.

- Rejection of baptism: based on Jesus' word about the living water, they perceived listening to the Gospel as Baptism ${ }^{27}$.

- Mythological notions

It seems that among the religious beliefs of Paulicians there were mythological notions that did not originate from their peculiar interpretation of the New Testament. For example, Petrus Siculus tells about their strange rituals during thunder storms $^{28}$. Euthymius Zigabenus mentions that they thought that evil (most likely - the god of matter and the present world) had originated from fire and darkness. $\mathrm{He}$ also notices that Paulicians avoided saying that fire was created by evil ${ }^{29}$. It is possible for this notion to have been taken from some Gnostic system including different stages of emanations, but this is merely speculation.

One relatively late Armenian legend referring to Paulicianism notices that Paulicians worshiped "sunny Christ" who had never died nor resurrected and kept the fast on Sunday ${ }^{30}$. On this basis the Bulgarian researcher of Paulicianism Donka Radeva regards the so-called "Paulician Christ" as a Christianized Mithraic god/cult ${ }^{31}$.

In my opinion Paulicianism followed a secret sun cult; its exact origin and the exact place of the "Paulician Christ" in this cult are unclear, but probably it originated outside the scope of dualistic doctrines.

\section{Paulicians in Bulgarian lands}

At first glance, evidence about the spread of Paulicianism in Bulgarian lands chronologically precedes evidence about Bogomilism with almost two centuries. The Byzantine author Theophanes Confessor notices that in the middle of the $8^{\text {th }}$ century the Byzantine emperor Konstantinos V brought Syrians and Armenians from Melitena and Theodosipolis and settled them in Thrace. Judging from the immediate reactions of Bulgarians, this migration must have affected the border

\footnotetext{
${ }^{25}$ Petrus Siculus, Historia, p. 12-13.

${ }^{26}$ Petrus Siculus, Historia, p. 14.

${ }^{27}$ Petrus Siculus, Historia, p. 37; Euthymius Zigabenus, Panoplia Dogmatica ad Alexium Comnenum (cetera: Euthymius, Panoplia), [in:] PG, vol. CXXX, col. 1197.

${ }^{28}$ Petrus Siculus, Historia, p. 25.

${ }^{29}$ Euthymius, Panoplia, PG, vol. CXXX, col. 1199.

${ }^{30}$ S. Dadoyan, The Fatimid Armenians..., p. 73, also Д. РАДЕва, Павликяни..., p. 515.

${ }^{31}$ Д. РАДЕвА, Павликяни..., р. 102-105.
} 
zone (with the early medieval Bulgarian state) of Northern Thrace. Subsequently, again according to the narrative of Theophanes Confessor, this population started spreading Paulicanism ${ }^{32}$.

In the second and the third decade of the $9^{\text {th }}$ century the territories of Northern Thrace were gradually incorporated in Bulgaria. During this conquest many inhabitants of Northern and Eastern Thrace were removed to Moesia, the cradle of the early medieval Bulgarian state. Thus an unknown number of people with dualistic ideas were incorporated in the territory of Bulgaria. Theophanes Confessor calls their dualism "Paulicianism" ${ }^{33}$ but mentions nothing about the essence of this "Paulicianism". Judging from John Exarch's evidence and the character of the Bogomil teachings, it could be concluded that the religious ideas propagated by the new settlers were some early from of Paulicianism, different from those of Tephrice, or most likely dualistic notions labeled as "Paulicianism". The existence of some Paulician groups in this early period cannot be excluded, but their influence on the dualistic movements in the Balkans was insignificant.

Petrus Siculus explicitly notes that around 870 Paulicians in Tephrice intended to send a mission to Bulgaria in order to propagate their doctrine among Bulgarians. That inspired him to write his work and to dedicate it to the Bulgarian archbishop ${ }^{34}$. However, we do not know whether Paulicians realized this decision. Having in mind the events after 870 and the recent collapse of the Paulician state as well as the lack of information about such a mission from another source, most likely this intent remained unrealized.

For sure the first Paulicians were settled in Philippopolis/Plovdiv ${ }^{35}$ shortly after the Byzantine reconquest of Northern Thrace in 970. This migration was initiated by emperor John I Tzimiskes who aimed to reduce their number in the eastern parts of empire ${ }^{36}$. In the following $11^{\text {th }}$ and $12^{\text {th }}$ centuries Philippopolis/Plovdiv became a center of religious and political Paulicianism. For example, Anna Comnena notes that in the second half of the $11^{\text {th }}$ century Philippopolis/Plovdiv and its vicinity became "heretical" and that the small number of Orthodox Christians were oppressed and regularly plundered by Paulicians ${ }^{37}$.

\footnotetext{
32 Theophanes Confessor, Chronographia, [in:] FGHB, vol. III, ed. I. Dujčev et al., Sofia 1960 (cetera: Theophanes Confessor, Chronographia), p. 269-270.

33 Theophanes Confessor, Chronographia, p. 269-270.

${ }^{34}$ Petrus Siculus, Historia, p. 2-3.

${ }^{35}$ During the Middle Ages this town was called in the Byzantine sources with its ancient Greek name Philippopolis but in some Bulgarian sources it appears with the name Plodiv or Plŭpŭdiv. The Bulgarian form has stemmed from the Moesain variant of the name of the city - Pulpodeva. However the change $\mathrm{u}>\mathrm{o}$ and the elision of the second syllable indicate Vulgar Latin mediation. In the article I use both names.

${ }^{36}$ Georgit Cedreni, Ioannis Scylitzae, Historiarum compendium, [in:] FGHB, vol. VI, ed. P. TivČEv et al., Sofia 1965 (cetera: Georgir Cedreni, IoAnnis Scylitzae, Historiarum compendium), p. 260. ${ }^{37}$ Anna Comnena, Alexias, [in:] FGHB, vol. VIII, ed. M. Vojnov et al., Sofia 1972 (cetera: Anna Comnena, Alexias), p. 137.
} 
During the same period the "absolute dualism", which was typical of Paulicians, started spreading among the dualistic communities in the Balkans and Western Europe $^{38}$. Some researchers tend to identify the so-called "church Durgunthia" known from the work of Rainer Sacconi as one of the two initial dualistic communities in Europe ${ }^{39}$, with the Paulicians inhabiting Philippopolis/Plovdiv. Most likely this "church" as well as the other main initial "church" called "Bulgaria", was Bogomilian $^{40}$. Anna Comnena explicitly states that besides Paulicians, Bogomils also lived in Philipopolis/Plovdiv ${ }^{41}$. However, "Durgunthia" obviously accepted the "absolute dualism" as a result of the Paulician influence.

The Paulicians from Philippopolis/Plovdiv, following the model inherited from Tephrice and Anatolia, formed their own military units, and many times they acted in unruly ways. For example, in 1079 the Paulician Leka rose in revolt in Sofia. Several years later the Paulician military commanders Xant and Kuleon refused to join in the military campaign against the Normans. The peak of their political activity was in 1084, when the local Paulicians under the leadership of Travlos seceded from Byzantine and formed their quasi state, whose center became the fortress Belyatovo - somewhere in modern central Bulgaria ${ }^{42}$. The events of 1084-1086 resembled those from the $9^{\text {th }}$ century, when a Paulician state hostile to Byzantine was founded in Asia Minor. It seems that after the Travlos' riot the military power of Paulicians declined. They appeared in the historical chronicles again in 1205 when they actively supported the Bulgarian tsar Kaloyan in his campaign against the Greeks and the Latin Empire. However, this time they acted not as a military unit but as a community inhabiting Philipopolis/Plovdiv, which was besieged by the army of Kaloyan ${ }^{43}$. It seems that this cooperation became the reason for their integration in the Second Bulgarian Tsardom - for example there is no evidence that they were pursued during the counsels against Bogomils, the socalled "Judean followers" and some other heretic communities in the $13^{\text {th }}$ and $14^{\text {th }}$ centuries. After 1205 they started to migrate from their homeland in the region of Philippopolis/Plovdiv northward, and most of them settled in the cradle area of the Second Bulgarian state, the so-called district of Zagora, a region between the Central Stara Planina Mountain and the Danube. Most of their $16^{\text {th }}$ and $17^{\text {th }}$ century settlements are registered in the region between Tărnovo and Nikopol, some of them in modern North Western Bulgaria, and only a small part of them

\footnotetext{
${ }^{38}$ Д. АНГеЛОв, Богомилството..., p. 354-355.

${ }^{39}$ Rainer SACConi, Summa fratris Raynerii de ordine fratrum praedicatorum, de Catharis et Pauperibus de Lugduno, [in:] FLHB, vol. IV, ed. M. Vojnov et al., Sofia 1981 (cetera: RAINER SACCONI, Summa), p. 169-170.

${ }^{40}$ Rainer Sacconi, Summa, p. 169.

${ }^{41}$ Anna Comnena, Alexias, p. 136.

${ }^{42}$ Д. РАДЕВА, Павликяни..., p. 198-208.

${ }^{43}$ Geoffrey de Villehardouin, Memoirs or Chronicle of the Fourth Crusade and the Conquest of Constantinople, London 1908, p. 105.
} 
remained south of the Stara Planina mountain ${ }^{44}$. Paulicians inhabiting the northwesternmost parts of Bulgaria (the territories of the so-called Vidin Tsardom) were mentioned in the sources referring to the period between the $1365-1369^{45}$.

In the centuries of the Ottoman rule, and especially in the $17^{\text {th }}$ century, some Paulicians adopted Islam, others were converted to Orthodoxy, but the most part of them embraced Catholicism as a result of the activity of the order of St. Francis and The Congregation for the Evangelization of Peoples / Congregatio pro Gentium Evangelizatione ${ }^{46}$. At the first half of the $18^{\text {th }}$ century one part of the Catholic Paulicians left the Ottoman Empire and settled in the region of Banat - then under the rule of Habsburgs ${ }^{47}$.

\section{Ethnical and language characteristics of the Balkan Paulicians}

After the $10^{\text {th }}$ century the Paulicians in Bulgarian lands experienced a process of linguistic Bulgarization. Its intensity and duration cannot be reconstructed, but in the $16^{\text {th }}$ and the $17^{\text {th }}$ century all available documents confirm that all Paulicians in the Balkans spoke Bulgarian. The linguistic investigations on Paulician vernaculars categorically show that the vernacular of all of them - these in Thrace, Moesia and Banat belong to a common dialect part of the Rhodope dialect group of Bulgarian ${ }^{48}$. That means that the process of Bulgarization of their language had ended before their migration to Moesia. Besides, the Catholic missioners explicitly noted that among Paulicians they found New Testament books written in parchment with Cyrillic letters in Slavonic (Old Slavonic or Middle Bulgarian???) and they even used them in their missionary activity ${ }^{49}$. Unfortunately, none of these books has been preserved, but Peter Bogdan (Deodat) Bakshev in 1650 mentioned that the books used by the Paulicians from the region of Plovdiv had been written on parchment more than 300 years before ${ }^{50}$. If this chronologization is correct, the Old Slavonic or Middle Bulgarian must have been used among Paulicians as a literary language at least since the first half of the $14^{\text {th }}$ century.

However, there are direct and indirect evidences that in the $10^{\text {th }}$ and $11^{\text {th }}$ century Paulicians were a heterogeneous linguistic and ethnic community.

\footnotetext{
${ }^{44}$ М. Йовков, Павликяни и павликянски селища в българските земи XV-XVIII век, София 1991, p. 105-162.

${ }^{45}$ Д. РАДЕвА, Павликяни..., р. 239.

${ }^{46}$ М. Йовков, Павликяни..., p. 71-88.

${ }^{47}$ С. Елдъров, Католиците в Бблгария. Историческо изследване, София 2002, p. 18-19.

${ }^{48}$ С. Стойков, Българска диалектология, София 1993, р. 137.

${ }^{49}$ De statu ecclesiae Petri archiepiscopi Sophiensis relatio CXVI. A. 1650, [in:] Eusebius Fermendzsin, Acta Bulgariae ecclesiastica ab a. 1565 usque ad a. 1799, Zagrabiae 1887 [= MSHSM, 18], p. 208. Also: Л. Милетичъ, Нашитю павликяни, [in:] Сборникъ за Народни Умотворения, Наука и Книжнина, vol. XIX, София 1903, p. 11.

${ }^{50}$ De statu ecclesiae Petri archiepiscopi..., p. 208; Л. Милетичъ, Нашить павликяни..., p. 11.
} 
- Armenians: Usually almost all contemporary authors assert that the initial Anatolian Paulician community included many Armenians ${ }^{51}$ and probably Syrians ${ }^{52}$ having in mind the evidences of Theophanes Confessor (see above). Anna Comnena also notices that Armenians and Syrians followers of Jacob bar Addai joined the Paulician community in Philippopolis/Plovdiv ${ }^{53}$. This evidence is not very clear, but it seems that disciples of the Armenian and the Syriac churches made a political alliance with the local Paulicians or even adopted their faith.

- Several heretical leaders are anathematized in the $77^{\text {th }}$ paragraph of the medieval Bulgarian Synodic of tsar Boril immediately after the anathemas pronounced against the founders of Paulicianism in the $76^{\text {th }}$ paragraph. The names men-

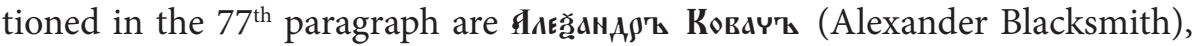
Явдинъ (Avdin), Фотинъ (Fotin), Ффригїи (Afrigii), Мшгси (Moses) ${ }^{54}$ and are unknown from other sources ${ }^{55}$. From them only Moses who is the last in the list is identified as Bogomil ${ }^{56}$. That gives reason to think that the other were adherents of Paulicianism. Avdin and Fotin are obviously Slavinized forms of the

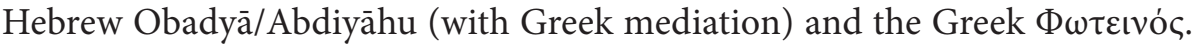
Separate attention must be paid to the name Afrigii. Probably that is a variant of the Chorasmian Iranian antroponym Afrig ${ }^{57}$. Most likely it belonged to some traditional layer in the Paulician anthroponymy and such like the origin of the group name Paulician(s) (see note 2) indicates Iranian traces in the very early history of Paulicanism.

- Semitic elements - except the above mentioned testimony of Anna Comnena, the names of one of the spiritual leaders of the Paulicians from Philippopolis/Plovdiv in the middle of the $11^{\text {th }}$ century, Kov'oivoc/Kusin ${ }^{58}$ indicates contacts with a Semitic environment. Most probably it is an adoption of the Arabic Husayn or of some of its variants - Husseyn, Husein, etc. The close contacts between the early Paulicians and Arabs in Anatolia and Syria are well

\footnotetext{
${ }^{51}$ Petrus Siculus, Historia, p. 27.

${ }^{52}$ Petrus Siculus asserts that Paulicanism emerged in Samosata - town in Armenia. However according to other sources this town is found in Syria - Euthymius, Panoplia, PG, vol. CXXX, col. 1190. ${ }^{53}$ Anna Comnena, Alexias, p. 137.

${ }^{54}$ That is according to the edition of Poprujenko in 1928. According to the new edition of the text of Synodic these anathemas are included in paragraph $23 \mathrm{~A}, 12-13$ lines: И. Божилов, А. ТотомАнова, И. Билярски, Борилов синодик. Издание и превод, София 2010.

${ }^{55}$ Ibidem, p. 34.

${ }^{56}$ М. Попруженко, Синодик иаря Борила, София 1928, р. 68.

${ }^{57}$ C. Bosworth, "ĀL-E AFRĪG", [in:] Encyclopcedia Iranica, vol. I.7, ed. E. Yarshater, Costa Mesa 1996 (online edition), http://www.iranicaonline.org [14 V 2014], p. 743-745.

${ }^{58}$ Anna Comnena, Alexias, p. 13.
} 
testified in the sources ${ }^{59}$. The etymology of the name of the second Paulician leader - Kou $\lambda \dot{\varepsilon} \omega v /$ Kuleon is uncertain. However it directs to the Latin oikonym "Colonia", a designation of an Anatolian settlement, which became the center of Constantin Silvan's activity and where, according to the narrative of Petrus Siculus and Euthymius Zigabenus, a Paulician community called "Macedonia", named after the church found by St. Paul, was established ${ }^{60}$. The reduction of the unstressed $\mathrm{o}(\mathrm{o}>\mathrm{u})$ is a regular occurrence in almost all Balkan languages, including many eastern Bulgarian and Greek dialects.

Besides, the above mentioned Bulgarian legend about the origin of Bulgarian Paulicians, tells about two "disciples" of the devil who left Cappadocia and come to Bulgarian lands, where they started to spread their teachings. The name of the first is given as С४готии/Subotin and the name of the second as Ш४тиль/ Šutil. In spite of its apocryphal character, the legend contains correct information about the practices of the early Paulicians - for example, the two disciples of devil changed their names, adopting the names of the apostles Paul and John ${ }^{61}$. The first name stems from the Old Slavonic (Bulgarian) word сквота/Saturday and up to the present day continues to be in use among Bulgarians ${ }^{62}$. The second name is unusual and with obscure etymology. However, having in mind that the devil was mentioned in the narrative, a link with the Syriac word šwdl, šwdl? (šuddāl, šuddālā) - lure, bite ${ }^{63}$ could be presumed.

- Turkic elements: The connections of the Paulicians from Philippopolis with the Turkic Oghuz tribes of Pecheneges, who in the middle of the $11^{\text {th }}$ century occupied the North Eastern parts of the Balkans, are well testified in the contemporary sources. Pecheneges were the main allies of Leka and Travlos and regularly supported Travlos' campaigns against Byzantium. Besides, there is categorical evidence that both Leka and Travlos were in matrimonial relations with Pecheneges ${ }^{64}$. The latter indicates a possible spread of Paulicianism among Pecheneges who were pagans in that period.

- Balkan elements: There is circumstantial evidence that while still in Anatolia, Greeks or Greek-speaking followers had strong standing in Paulician communities, and even that Greek was the main colloquial and written language

\footnotetext{
${ }^{59}$ М. БАРТикян, К вопросу о павликианском движении в первой половине VIII в., ВВ 8, 1956, p. 127-128; Д. РАДЕВА, Павликяни..., p. 337-339.

${ }^{60}$ Petrus Siculus, Historia, p. 32, 48.

${ }^{61}$ Слово как се появиха павликяните..., р. 517.

${ }^{62}$ С. Илчвв, Речник на личните и фамилните имена у бблгарите, София 1969, p. 472.

${ }^{63}$ The Compendious Syriac Dictionary, ed. J. Payne Smith, Oxford 1903, p. 561.

${ }^{64}$ Anna Comnena, Alexias, p. 52-54; Georgi Cedreni, Ioannis Scylitzae, Historiarum compendium, p. 339.
} 
of Paulicians ${ }^{65}$. The names of some of the $11^{\text {th }}$ century leaders of the Paulicians

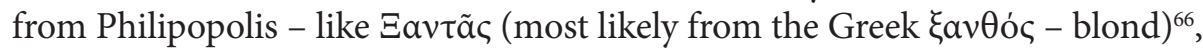
Tpau入ó $\varsigma$ and $\Phi \tilde{\omega} \lambda \varsigma^{67}$ are Greek popular anthroponyms and indirectly prove that one part of the local Paulicians were Greeks or at least strongly influenced by the Greek popular anthroponymic practices. Another interesting anthroponym is the name $\Lambda \dot{\varepsilon} \kappa \alpha \varsigma / L e k a$ - an Albanian adoption of the Greek 'A $\lambda \dot{\varepsilon} \xi \alpha \nu$ $\delta \rho o \varsigma^{68}$, which probably indicates that Paulicians in the $11^{\text {th }}$ century succeeded to spread their influence over Albanian groups. The phonetic characteristics of the name of the mountain village founded near the mountain pass and the road which connected the mediaeval Sredets (Sofia) and Philippopolis/Plovdiv give reasons to think that in the $10^{\text {th }}$ and $11^{\text {th }}$ century some mountain regions between both towns were inhabited by (Proto) Albanian population which had migrated eastward from their native lands in the Central and Western Balkans $^{69}$. In this context the appearance of an Albanian anthroponym in a Paulician community is not a surprise, but it also shows that Paulicians directed their efforts towards the nearby mountain communities. This circumstance can explain their subsequent Slavinization by means of the Bulgarian Rhodope dialects, which initially must have functioned as a "lingua franca".

Of course, the assumption that different ethnical identities existed within the medieval Paulician community in the Balkans parallel with the main Paulician identity is controversial. All medieval sources represent Paulicians as a monolithic community, consolidated around their heretical beliefs and religious and military leaders. On the other hand, representatives of the Paulician Catholic intellectuals, e.g. Philip Stanislavov in the $17^{\text {th }}$ century, obviously considered themselves Paulician Bulgarians. Indeed, it could be a result of the influence exerted by Catholic missionaries who identified Paulicians as Slavs and Bulgarians, but the author of the apocryphal legend about the origin of Paulicians, who was not under the

${ }^{65}$ Д. РАДЕВА, Павликяни..., p. 113-115.

${ }^{66}$ Б. Янев, Нов поглед върху грбиките лични имена в българската антропонимна система, НТПУПХ 51, 1, 2013, p. 466.

${ }^{67}$ Anna Comnena, Alexias, p. 43.

${ }^{68}$ Albanian Personal Names, Washington 1966 (electronic edition prepared by E.E.D. Lawson and R.F. SHEIL), p. 28.

${ }^{69}$ That is the oikonym ЏЏпон' (Štipon) recorded in the Bitola inscription of the Bulgarian tsar Ivan Vladislav from 1015 (Й. ЗАимов, Битолски надпис на Иван Владислав, старобългарски паметник от 1015-1016, София 1969, p. 26). Phonetically it stays very close to another Middle Bulgarian oikonym - Штипь (Shtip - at the present in Republic of Macedonia) recorded in the Apocryphal Bulgarian chronical from the $11^{\text {th }}$ or $12^{\text {th }}$ century (Й. ИвАнов, Богомилски книги и легенди, София

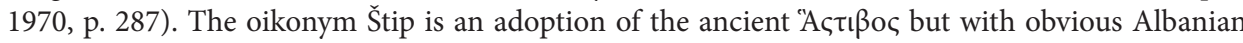
mediation (V. STANIšić, Two Types of Ancient Indo-European Isoglosses in the Albanian Language, Balc 29, 1998, p. 323). The same unusual of the Old Slavonic adoption of the initial s by means of š is regarded in the case of Štipon that also indicates an Albanian mediation. 
influence of the Catholic Church, considered them Bulgarians who had accepted the teachings of the devil ${ }^{70}$. This indicates that ethnic awareness (autonomous from religious awareness) among Paulicians was not a completely unknown phenomenon and that the existence of some ethnical segmentation in the Paulician community in the $11^{\text {th }}-13^{\text {th }}$ centuries cannot be excluded. The latter seems to have remained invisible to foreign observers and to have been based on language differences and pre-Paulician clan and ethnical relations. However, Slavinization, which in practice was a process of linguistic and probably ethnic unification, indicates that all of these language and ethnic differences were overcame relatively early - most likely circa the end of the $12^{\text {th }}$ century, but the reasons and factors that led to that remain obscure.

\section{Paulicians in the $17^{\text {th }}$ century}

Although some of the western travelers, Dubrovnik traders and even Catholic missioners in the Ottoman Empire give interesting evidence about the Bulgarian Paulicians as early as the $16^{\text {th }}$ century, the first detailed reports about them are from the early $17^{\text {th }}$ century. Then they attracted the attention of the Bosnian Franciscans, the Catholic Congregation for the Propagation of Faith (Sacra Congregatio de Propaganda Fide) and the Catholic Archbishopric of Sofia, created in 1601, whose center was in Chiprovtsi, an old center of Bulgarian Catholics located in the northwesternmost Bulgarian ethnic territories. The initial year of the Catholic activity among Paulicians is considered to be $1604^{71}$. From this moment on a big number of reports concerning different sides of religious and social life of the Bulgarian Paulician communities have been written and sent to Rome by the Catholic missioners and bishops. Among the authors of these reports are the most significant representatives of the $17^{\text {th }}$ century Bulgarian Catholic intelligentsia - Peter Bogdan Bakshev, Anton Stefanov, Filip Stanislavov etc. The latter was not only Bulgarian by origin but also of Paulician origin. The reports in question registered a situation which in many aspects was quite different from that in the Middle Ages:

- The ethnical structure of Paulicians - unlike their counterparts in the previous epoch, all Paulicians in the $17^{\text {th }}$ century spoke only Bulgarian. Their anthroponym system was composed entirely of popular Bulgarian names. The books found by missionaries were the texts of Gospels, Acts of the Apostles, Epistles of Paul, and Book of Revelation - all of them written in Slavonic with Cyrillic

\footnotetext{
${ }^{70}$ According to the second variant of the legend known from the manuscript dated back to the $18^{\text {th }}$ century Paulicians thought Bulgarians and glorified Paul. Many Bulgarians accepted the law from these devils and became to be called Paulicians (in Д. РАдевА, Павликяни..., p. 520).

${ }^{71}$ М. Йовков, Павликяни..., р. 76.
} 
letters ${ }^{72}$. The archbishop Peter Bakshev constantly notices in his reports that the Paulicians from Thrace are Slavs by origin ${ }^{73}$.

- The dualistic doctrine: paradoxically, missionaries and bishops, including Filip Stanislavov, mention nothing about dualistic notions in their reports. The disappearance of dualism preceded the activity of Catholic missionaries, but the exact time of this disappearance remains unknown.

- The Paulicians had adopted some elements of the Orthodox holiday and canonical system - the Friday fast, the Easter fast, the fast preceding the day of Virgin Mary (15 August), the celebration of Sundays, the main Christian holidays fixed in accordance with the Julian calendar. They celebrated some "personal" holidays, such as these of St. Barbara or St. Sava ${ }^{74}$. Most probably these "personal" days were days of the saints whose names belonged to separate persons. The influence of the Orthodox calendar on them was so strong that even decades after their conversation to Catholicism they refused to accept the calendar of the Catholic Church ${ }^{75}$.

The significant changes in the beliefs and practices of Paulicians most likely resulted from the influence of different sources. In the first place the activity of the medieval Tărnovo Patriarchy should be mentioned. Its struggle against Bogomilism and other heretical groups is well testified. It is significant that none of these groups survived after the $14^{\text {th }}$ century. However, the Paulicians, most likely for political reasons, were in the periphery of the anti-heretical activity of Tărnovo Patriarchy, which led to the decline of their dualistic doctrine. Another source of this change most likely was their everyday contacts with the Orthodox Christians. For example Peter Solinat notices that Paulicans often married their daughters to Orthodox Christians and even to Turks ${ }^{76}$. The practices of exogamy also should contribute to the decline of dualistic notions and beliefs.

However Paulicians in the sphere of normative culture, prohibitions and rituals, continued to keep their previous practices and notions. The most important of them were the categorical rejection of the Holy Cross and icons, ignorance of

\footnotetext{
${ }^{72}$ Fr. Petri Bogdani Bakšić, episcopi Gallipoliensis et coadiutoris Sophiensis, de statu ecclesiae suae relatio accuratissima cum notis cuiusdam in margine adpostis L. A. 1640, [in:] Eusebius Fermendzsin, Acta Bulgariae ecclesiastica..., p. 80.

${ }^{73}$ Петър БАкшев, Доклад на собийския архиепископ Петър Богдан Бакшев за състоянието на неговата архиепископия, [in:] Б. Примов, П. САРИЙСКИ, М. ЙовКОв, Документи..., p. 85-87.

${ }^{74}$ Антон СТефанов, Доклад за посещението на Никополския епископ, [in:] Б. Примов, П. САРиЙСки, М. Йовков, Документи... (cetera: Антон СтЕФАнов, Доклад), p. 482.

${ }^{75}$ Антон СтефАнов, Доклад, p. 482, 485-486.

${ }^{76}$ Петър Солинат, Доклад, р. 22.
} 
the church sacraments, the Biblical books out of the Paulician "canon"77 and clergy. The Paulicians chose their priests among the literate people in their communities, an indication that among them there were some forms of primitive education. Their services consisted of common feasts that they made in their churches or in houses ${ }^{78}$.

\section{The legend}

The complete variant of the legend is recorded by Bishop Filip Stanislavov in 1637. According to the legend, Paulicians originated from Rome, where the four Gospels were written by one Paulician tsar named Silivič and were preserved in Rome. Silivič was a pious and devout Christian who spread Christianity all over the world. The Paulicians considered themselves Romans, although Rome and the Pope were so far that in practice no man could reach them ${ }^{79}$. The other missionaries were also familiar with the legend about the Roman origin of Paulicians. For example, Peter Bakshev tried to find some rational explanation of this claim and maintained the view that Paulicians had brought their faith from Bosnia, and this had given rise to the legend about Rome ${ }^{80}$. Other Catholics had heard and accepted entirely this legend even before the appearance of the Catholic mission - for example, the monk from Dubrovnik, Mavro Orbini, in his work Il regno de gli Slavi, published in 1601, described their migration from Rome to the Balkans ${ }^{81}$.

The legends about Rome and the Pope were widespread in the Bulgarian popular culture from the Middle Ages on. Some of them are based on real historical and religious facts - many of the early popes were saints of the Orthodox Church, and in the $9^{\text {th }}$ and $10^{\text {th }}$ century Bulgarians were in close contacts with Papacy; according to the Old Bulgarian bookman Presbyter Kozma in the same period many Bulgarian monks visited Rome and Jerusalem as pilgrims ${ }^{82}$, in the $12^{\text {th }}$ century the legend that one of the most honored Bulgarian saints - St. Tsar Peter (927-969) died in Rome gained popularity ${ }^{83}$; at the beginning of the

\footnotetext{
${ }^{77}$ It is remarkable that Bulgarian Paulicians in the $17^{\text {th }}$ century in spite the influence exerted by the Orthodox Christians and in spite the change of the language code used almost the same books of New Testament that were in use among the Paulicians in Tephrice eight centuries earlier - Petrus Siculus, Historia, p. 26. Probably the only one difference was the Book of Revelation.

${ }^{78}$ Л. Милетичъ, Нашитю павликяни..., p. 22-23; also Петър Солинат, Доклад, р. 22.

${ }^{79}$ Philippus Stanislavov de Pavlićianorum origine eorumque libris sacris secundum vulgi opinionem quaedam enarrat XXXIX. A. 1636, 3. Augusti, Orešče, [in:] Eusebius Fermendzsin, Acta Bulgariae ecclesiastica..., p. 42; Л. Милетичъ, Нашить павликяни..., p. 10.

${ }^{80}$ Fr. Petri Bogdani Bakšić, episcopi Gallipoliensis..., p. 79-80; Л. Милетичъ, Нашитю павликянu..., p. 11.

${ }^{81}$ Mavro Orbini, Il regno de gli Slavi (1601), [in:] Д. РАДЕвА, Павликяни..., p. 535-536.

82 ПрезвитеРъ КозмА, Беседа против богомилитт, София 1939, р. 46.

${ }^{83}$ Й. ИвАНОВ, БогомИЛсКИ..., р. 285.
} 
$13^{\text {th }}$ century the Bulgarian church proclaimed a union with Papacy, and even the Bulgarian Tsar Kaloyan insisted on his Roman origin ${ }^{84}$. Rome is regular mentioned in the historical books, biographies of saints and apocrypha, translated to or created in Old Slavonic and Middle Bulgarian etc.

However, there are strong reasons to think that the legend appeared in a Paulician environment and was not borrowed from foreign sources. For instance, the mysterious tsar Silivič and the concept that the Gospels were preserved in Rome are not found in other sources. Some researchers tend to identify Silivič with the Paulician religious leader from the end of the $7^{\text {th }}$ century, Constantine. He changed his name to Silvan, one of the followers of St. Paul ${ }^{85}$. As a name Silivič most likely is a distorted variant of the Slavic/Bulgarian diminutive form ${ }^{\star}$ Silvanič. Petrus Siculus asserts that Constantine-Silvan created the Paulician canon of holy books, eliminating all Manichean scriptures and imposing the Gospels and the Acts of Apostles as the only books that must be read by Paulicians ${ }^{86}$.

In this case having in mind the early Paulician tradition - their communities to be named after the churches found and after the places visited by St. Paul, "Rome" could be identified with some of the Paulicians' "strongholds". Most probably this was the name of their community in Philippopolis/Plovdiv. The town was the westernmost point of their migration in the $10^{\text {th }}$ century and the most active center of their faith in the $11^{\text {th }}$ and $12^{\text {th }}$ century.

Another interesting moment in favor of this hypothesis is that the popular designation of Northern Thrace, including the region of Philippopolis/Plovdiv, during the Middle Ages and in the centuries to follow, was Romania or Rumanya (popular pronunciation). This horonym is spread in many medieval Bulgarian and Byzantine documents of formal and popular origin ${ }^{87}$. It continued to be in use up to the beginning of the $20^{\text {th }}$ century and can even be found in the works of Bulgarian writers from the first half of the $20^{\text {th }}$ century.

${ }^{84}$ Innocentii III papae et Caloiahannis regis, [in:] FLHB, vol. III, ed. I. DUJČEv et al., Sofia 1965, p. 308-309.

85 Д. РАДЕвА, Павликяни..., р. 380-381.

${ }^{86}$ Petrus Siculus, Historia, p. 31-32.

${ }^{87}$ The formal medieval documents of Bulgarian origin where the horonym Romania can be met are the stone inscription of tsar John Asen II in the church of "St. Forty Martyrs" (1230) - Veliko Tărnovo, the panegyric dedicated to tsar John Alexzander in Sofia/Kuklen Psalter (1336), The biography of Saint Michael from Potuka written by the Tărnovo patriarch St. Euthymius in the 1380ies. The horonym is known also from medieval sources of popular origin: an inscription from Preslav dated back to the $10^{\text {th }}$ century, the Bulgarian Apocryphal chronicle from the $11^{\text {th }}-12^{\text {th }}$ century, the inscription of Ivo grammarian from the Ivanovo rock monastery (around 1321-1322). The same horonym is exclusively popular in the Bulgarian folklore especially in harvester's folk songs. 


\section{The ritual - baptism of fire}

The most impressive Paulician ritual that in 1661 attracted the attention even of the British diplomat Paul Rycaut ${ }^{88}$, was the so-called baptism of fire. According to the description of Bishop Peter Bakshev, it was performed by Paulician priests. They touched the four sides of the head of a "baptized" person with burning candle ${ }^{89}$. The ritual was preserved among Paulicians long time after their conversation to Catholicism, but then it was performed not by priests but by elderly women, who on 6 January (the winter holiday dedicated to St. John the Baptist) visited the houses of newly baptized children, carried out the ritual and even used to singe children's hair ${ }^{90}$. A similar custom has not been registered among the non-Paulician inhabitants of the Balkans; therefore it was not borrowed from the local population. Peter Bakshev sheds additional light on the origin and nature of the ritual, adding that it was called "baptism with the fire of Saint John the Baptist" ${ }^{\text {"I }}$. In the Orthodox calendar, there are two holidays dedicated to St. John - one in winter and another on 24 June. In folk beliefs and practices, the summer holiday is closely related to the pagan sun cults. That gives serious reasons to think that the ritual was a relic from a peculiar Paulician sun cult, and most probably was a kind of initiation. It is remarkable that this relic survived much longer than dualism. Actually, this fact indicates that dualism was not the only one and the longest lasting characteristic of the Paulician religious system. The existence of a similar cult, separate from dualistic notions, is proved by the following facts:

- As I mentioned above, one of the designations of Mẹzghnean in early medieval Armenia was Sun Worships. The Armenian legend also confirms the Paulician cult of "Sunny Christ".

- The Bulgarian bookman John Exarch testifies that according to Manicheans, the sun was "autonomous/self-governing" - several decades before the appearance of Bogomilism. Therefore, in this period Paulicians were the only group in Bulgaria which could be called "Manicheans". In the same book he asserts that Manicheans believed that the earth had its own soul, and this belief had originated from their interpretation of the verse Let the land produce... $(\mathrm{Gn} 1,11)^{93}$, i.e. they believed in the creative power

${ }^{88}$ П. Рико, Сегашното състояние..., р. 175.

${ }^{89}$ Fr. Petri Bogdani Bakšić, episcopi Gallipoliensis..., p. 80.

${ }^{90}$ А. Янков, Из зимния циикъл на българските павликяни в Северна България, АПП 2, 1993, p. 26-28; Д. РАДЕвА, Павликяни..., p. 464.

${ }^{91}$ Fr. Petri Bogdani Bakšić, episcopi Gallipoliensis..., p. 80; Л. Милетичъ, Нашитю павликяни..., р. 23; Д. РАДЕВА, ПавликянИ..., р. 400.

92 ЙОАн ЕКЗАРХ, Шестоднев, София 1981 (cetera: ЙоАн ЕкзАРХ, Шестоднев), р. 142.

${ }_{93}^{93}$ Йонн ЕкзАрх, Шестоднев, р. 207. It is remarkable that in this and other cases described by Joan Ekzarh heretics used in favor of their theses passages from the Old Testament. This makes me think 
of the earth. Most likely they shared similar animistic notions about the sun. However, the connection of these notions with the dualistic doctrines is doubtful. They indicate a direct pagan influence on the belief system of Paulicians.

- Seta Dadoyan tends to classify the Paulician state of Tephrice as an Acritic state, i.e. a border state in the zone between the Byzantine and the Muslim world, with militarized autonomous population. In a later Acritic epos she found undoubted relics of Paulician views and lifestyle ${ }^{94}$. However, in the song of Armuris, part of this Acritic epos, traces of the sun cult are evident ${ }^{95}$. This indicates that the main followers of these animistic cults were male communities engaged in military activity. Paulicians continued to keep the military characteristics of their society long time after their migration to the Balkans. Probably that means that these male communities continued to exist in the new conditions, and the ritual should be ascribed to their influence.

According to the well-founded remark of one of the reviewers of the present article the so-called "baptism with fire" might be rooted in the gospel verse I baptize you with [a] water for repentance. But after me comes one who is more powerful than I, whose sandals I am not worthy to carry. He will baptize you with [b] the Holy Spirit and fire (Mt 3, 11); I baptize you with [a] water. But one who is more powerful than I will come, the straps of whose sandals I am not worthy to untie. He will baptize you with [b] the Holy Spirit and fire (Lc 3, 16). In my opinion the "baptism with fire" bears the characteristics of typical initiation referring to secret sun cult and does not stem from some different comprehension of baptism. Moreover the medieval authors mention nothing about similar ritual of baptism among "Paulicians" - they notice a completely different Paulician notion of baptism (see above). However, it is possible for the gospel verses to have been used as a theological justification of the ritual, which at some point, after the disintegration and disappearances of the militarized male communities, acquired the significance of baptism. That can explain the fact that in modern times "the baptism of fire" was carried out in the day of epiphany (the $7^{\text {th }}$ of January) ${ }^{96}$.

Some medieval Armenian sources reveal one additional characteristic of Paulicianism that can be defined as the darkest side of this heresy - children sacrifice ${ }^{97}$. Byzantine and Bulgarian sources do not mention such practices, but ethnographic studies on traditional folk culture of Bulgarian Paulicians discovered rituals

that the Syrians and Armenians who settled in Thrace in the mid $8^{\text {th }}$ century spread some form of Paulicianism different from this of Tephrice.

${ }^{94}$ S. Dadoyan, The Fatimid Armenians..., p. 51-52.

${ }^{95}$ Д. РАДЕвА, Павликяни..., р. 97-98.

${ }^{96}$ Ibidem, p. 463-464.

${ }^{97}$ Ibidem, p. 96. 
and customs that could be interpreted as reminiscences of similar sacrifices ${ }^{98}$. In my opinion, the problem needs a more detailed and thorough investigation, but if they really existed, they also should be attributed to male communities.

\section{Stoning}

Peter Solinat, the Catholic bishop of Sofia in 1601-1623, notices in his report to Rome that during his missions in the Paulician villages many times radical Paulicians threatened him with stoning ${ }^{99}$. It is interesting that in his biography of St. Ilarion, bishop of Maglen (the $11^{\text {th }}-12^{\text {th }}$ century), the last patriarch of Tărnovo, St. Euthymius (the second half of the $14^{\text {th }}$ century), narrates a similar story. According to St. Euthymius, a significant number of Armenians, Manicheans (obviously Paulicians) and Bogomils inhabited the eparchy of St. Ilarion. The bishop tried to convert them to Orthodoxy, and because of his devotion to this cause was attacked and stoned almost to death. The responsibility for this act was ascribed to Armenians ${ }^{100}$ but it is strange that according to the biography, their hatred for the bishop was provoked by the fact that many "Manicheans" left their initial beliefs and accepted Orthodoxy as a result of his activity ${ }^{101}$. The biography of St. Ilarion in the part concerning his life of bishop strongly resembles classical anti heretical treatise. For example the whole argumentation in the dispute with Armenians is entirely borrowed from the work of Euthymius Zigabenus. The only new moment is stoning and probably that reflects real practices and events.

Stoning is a punishment untypical of the Bulgarian normative culture and unknown in the Bulgarian medieval law ${ }^{102}$. On the other hand, it was widely spread in the Near East and was imposed for different reasons, including blasphemy and religious conversion. From the report of Peter Solinat it is evident that Paulicians who threatened him with stoning spurned his sermons about the Holy

${ }^{98}$ Ibidem, p. 462-463. Archimandrite Pavel Stefanov in his introduction in the Bulgarian edition of the work of the French historian Michel Tardieu - Le manichéism (М. ТАрдио, Манихействоmo..., p. 4), also maintains the view that some folk rituals among Bulgarian Paulicians indicate reminiscences of human sacrifices.

${ }^{99}$ Петър Солинат, Доклад, р. 22.

${ }^{100}$ ПатрИАРХ ЕвтИМИЙ, СбчИненИЯ, trans. К.И. ИвановА, praef. К.Т. ЯНАКИЕВ, СофИЯ 1990 [= БФН], p. 68-69.

${ }^{101}$ It is interesting that a settlement named "Pavlikyan" is registered in the $17^{\text {th }}$ century in the neighbor region of Castoria (М. Йовков, Павликяни..., p. 161) that indirectly supports the data of biography about the spread of Paulicanism in this relatively distant from Philippopolis/Plovdiv area.

${ }^{102}$ There is only one documented incident of stoning in the Bulgarian medieval history from 1040. Besides, in the $19^{\text {th }}$ century in some villages from the northwesternmost Bulgaria practices of a public curse that resembled symbolic stoning were recorded. It is interesting that in the earlier era Paulicians inhibited settlements in the same region (Л. Милетичъ, Нашитгь павликяни..., p. 10) and the practices in question might be a result of their influence. 
Cross, icons, and liturgy, as well as his attempts at converting them to Catholicism $^{103}$. In fact, they considered his sermons a kind of blasphemy. In this context their threats can be regarded not only as a result of emotional reactions against the Catholic missionaries but also as principles of their customary law.

Petrus Siculus explicitly notices that Paulicians knew and inflicted this kind of capital punishment on the religious dissidents even before Tephrice ${ }^{104}$. Therefore, it might be suggested that stoning was an element of the normative culture of the Bulgarian Paulicians which was directly accepted and inherited from their Anatolian ancestors.

\section{Conclusion}

The Paulicians in the $17^{\text {th }}$ century are an interesting example of a historical dualistic community that lost dualism during its long history. This paradox can hardly be explained if we regard dualism as the main factor in their religious notions and beliefs. Most probably it was an intellectual heretical doctrine adopted and imposed by their leaders. It created the frame of their religious legitimation, but it seems that the inner relations in the community were based on cults, notions and rituals which can be euphemistically called "folk religion". Of course, it does not mean that "pure" dualists did not exist, but their number must be insignificant. The testimony of Rayner Sakkony who explicitly mentions that the total number of the members of the dualistic (Bogomil and Cathar) communities in Southern France, Italy and Balkans was around $4000^{105}$ also supports the assumption that dualism was a religious ideology "comprehended" by relatively small number of people.

The contacts and clashes of Paulicians with the Orthodox Christians and their state and church institutions led to the disappearance of "classical dualism" - probably the weakest characteristic of Paulician identity, but inner relations, such as rituals of initiation, notions, taboos, customary law and myths of identity remained almost untouched.

\section{Bibliography}

\section{Primary Sources}

Anna Comnena, Alexias, [in:] Fontes graeci historiae bulgaricae, vol. VIII, ed. M. Vojnov et al., Sofia 1972, p. 7-149.

Anton Stefanov, Doklad za poseštenieto na Nikopolskija episkop, [in:] B. Primov, P. Sarijski, M. Jovкоv, Dokumenti za katoličeskata dejnost v Bălgarija prez XVII vek, Sofija 1993, p. 473-502.

\footnotetext{
${ }^{103}$ ПеТър Солинат, Доклад, р. 22.

${ }^{104}$ Petrus Siculus, Historia, p. 33.

${ }^{105}$ Rainer SaCConi, Summa, p. 170.
} 
De statu ecclesiae Petri archiepiscopi Sophiensis relatio CXVI. A. 1650, [in:] Eusebius Fermendzsin, Acta Bulgariae ecclesiastica ab a. 1565 usque ad a. 1799, Zagrabiae 1887 [= Monumenta spectantia historiam slavorum meridionalium, 18], p. 207-211.

Euthymius Zigabenus, Panoplia Dogmatica ad Alexium Comnenum, [in:] Patrologiae cursus completus, Series graeca, vol. CXXX, ed. J.-P. Migne, Paris 1865, col. 9-1362.

Fr. Petri Bogdani Bakšić, episcopi Gallipoliensis et coadiutoris Sophiensis, de statu ecclesiae suae relatio accuratissima cum notis cuiusdam in margine adpostis L.A. 1640, [in:] Eusebius Fermendzsin, Acta Bulgariae ecclesiastica ab a. 1565 usque ad a. 1799, Zagrabiae 1887 [= Monumenta spectantia historiam slavorum meridionalium, 18], p. 68-106.

Geoffrey de Villehardouin, Memoirs or Chronicle of the Fourth Crusade and the Conquest of Constantinople, London 1908.

Georgit Cedreni, Ioannis Scylitzae, Historiarum compendium, [in:] Fontes graeci historiae bulgaricae, vol. VI, ed. P. Tivčev et al., Sofia 1965, p. 198-340.

Innocentii III papae et Caloiahannis regis, [in:] Fontes latini historiae bulgaricae, vol. III, ed. I. DuJČEv et al., Sofia 1965, p. 307-373.

JoAn EKZarh, Šestodnev, Sofija 1981.

Mavro Orbini, Il regno de gli Slavi (1601), [in:] D. Radeva, Pavlikjani i pavlikjanstvo v bălgarskite zemi. Arhetip i povtorenija VII-XVII vek, Sofija 2015, p. 535-536.

Patriarh Evtimis, Săčinenija, trans. K.I. Ivanova, praef. K.T. JANAKiev, Sofija 1990 [= Българско Философско Наследство / Bălgarsko Filosofsko Nasledstvo].

PetĂR BAKšEv, Doklad na sofijskija arhiepiskop Petăr Bogdan Bakšev za săstojanieto na negovata arhiepiskopija, [in:] B. Primov, P. SARIJSKI, M. Jovkov, Dokumenti za katoličeskata dejnost v Bălgarija prez XVII vek, Sofija 1993, p. 44-107.

Petăr Solinat, Doklad na sofijskija episkop Petăr Solinat do săbornata kongregacija v Rim ot 1622 g., [in:] B. Primov, P. SARIJSKI, M. Jovkov, Dokumenti za katoličeskata dejnost v Bălgarija prez XVII vek, Sofija 1993, p. 20-23.

Petri Siculi Historia Manichaeorum seu Paulicianorum, Gottingae 1846.

Philippus Stanislavov de Pavlićianorum origine eorumque libris sacris secundum vulgi opinionem quaedam enarrat XXXIX. A. 1636, 3. Augusti, Orešče, [in:] Eusebius Fermendzsin, Acta Bulgariae ecclesiastica ab a. 1565 usque ad a. 1799, Zagrabiae 1887 [= Monumenta spectantia historiam slavorum meridionalium, 18].

Popruženko M., Sinodik carja Borila, Sofija 1928.

Prezviter" Kozma, Beseda protiv bogomilitě, Sofija 1939.

RaIner Sacconi, Summa fratris Raynerii de ordine fratrum praedicatorum, de Catharis et Pauperibus de Lugduno, [in:] Fontes latini historiae bulgaricae, vol. IV, ed. M. Vojnov et al., Sofia 1981, p. $159-178$.

Riko P., Segašnoto săstojanie na Osmanskata imperija i na grăckata cărkva (XVII vek), trans. et ed. M. KISELINČEva, Sofija 1988.

Slovo kak se pojaviha pavlikjanite, [in:] D. RADEva, Pavlikjani i pavlikjanstvo v bălgarskite zemi. Arhetip i povtorenija VII-XVII vek, Sofija 2015, p. 516-520.

Theophanes Confessor, Chronographia, [in:] Fontes graeci historiae bulgaricae, vol. III, ed. I. DUJČEV et al., Sofia 1960, p. 226-289. 


\section{Secondary Literature}

Albanian Personal Names, Washington 1966 (electronic edition prepared by E.E.D. LAwson and R.F. SHEIL).

Angelov D., Bogomilstvoto, Sofija 1993.

BARTIKJAn M., K voprosu o pavlikianskom dviženii v pervoj polovine VIII v., "Византийский временник" / "Vizantijskij vremennik" 8, 1956, p. 127-131.

Bolotov V., Lekcii po istorii Drevnej Cerkvi, vol. II, Istorija cerkvi v period do Konstantina Velikogo, Moskva 1994.

Bosworth C., "ĀL-E AFRĪḠ", [in:] Encyclopcedia Iranica, vol. I.7, ed. E. Yarshater, Costa Mesa 1996 (online edition), http://www.iranicaonline.org [14 V 2014], p. 743-745.

Božilov I., Totomanova A., Biljarski I., Borilov sinodik. Izdanie i prevod, Sofija 2010.

The Compendious Syriac Dictionary, ed. J. PAyne Smith, Oxford 1903.

Dadoyan S., The Fatimid Armenians. Cultural and Political Interaction in the Near East, Leiden 1997.

ELDĂrov S., Katolicite v Bălgarija. Istoričesko izsledvane, Sofija 2002.

Garsolian N., The Paulician Heresy. A Study of the Origins and Development of Paulicianism in Armenia and the Eastern Provinces of the Byzantine Empire, The Hague 1967.

ILČEv S., Rečnik na ličnite i familnite imena u bălgarite, Sofija 1969.

Ivanov J., Bogomilski knigi i legendi, Sofija 1970.

JANEv B., Nov pogled vărhu grăckite lični imena v bălgarskata antroponimna sistema, "Научни трудове на Пловдивски университет Паисий Хилендарски" / "Naučni trudove na Plovdivski universitet Paisij Hilendarski” 51, 1, 2013, p. 458-481.

JАNкоv A., Iz zimnija cikăl na bălgarskite pavlikjani v Severna Bălgarija, “Архив за поселищни проучвания" / "Arhiv za poselištni proučvanija" 2, 1993, p. 19-35.

Jovкоv M., Pavlikjani i pavlikjanski selišta v bălgarskite zemi XV-XVIII vek, Sofija 1991.

Miletič L., Našitě pavlikjani, [in:] "Sbornik” za Narodni Umotvorenija, Nauka i Knižnina, vol. XIX, Sofija 1903, p. 1-369.

Perichanjan A., K voprosu O Proischoždenii Pavlikianstva, “Письменные Памятники Востока" / "Pis'mennye Pamjatniki Vostoka" 2, 2011, p. 67-69.

Radeva D., Pavlikjani i pavlikjanstvo v bălgarskite zemi. Archetip i povtorenija VII-XVII vek, Sofija 2015.

Stanišić V., Two Types of Ancient Indo-European Isoglosses in the Albanian Language, "Balcanica" 29, 1998, p. 321-338.

Stefanov P., Jaldavaot. Istorija i učenie na gnostičeskata religija, Sofija 2008.

Sтојкоv S., Bălgarska dialektologija, Sofija 1993.

Tardio M., Manihejstvoto, Sofija 2001 (trans. from French: M. Tardieu, Le manichéism, Paris 1997).

Zaimov J., Bitolski nadpis na Ivan Vladislav, starobălgarski pametnik ot 1015-1016, Sofija 1969. 


\begin{abstract}
During the Middle Ages two dualistic communities were active in Bulgaria and Bulgarian lands - Bogomils and Paulicians. Paulicians, unlike Bogomils, survived as a separate religious sect up to the $17^{\text {th }}$ century, when most of them gradually accepted Catholicism. The detailed reports of Catholic missionaries, priests and bishops shed light on different aspects of their beliefs and practices from the $17^{\text {th }}$ century. The aim of the present article is to propose an explanation of a strange ritual and a legend spread among the Bulgarian Paulicians and recorded in the above-mentioned reports. The thesis of the article is that the legend and the ritual in question refer to the early history of Paulicianism. The ritual is related to syncretic religious notions and goes beyond the scope of dualism. I try to examine the legend and ritual in the context of Paulician history in the Balkans, especially in the context of Paulician belief system, inherited from the early Anatolian Paulicians.
\end{abstract}

Keywords: Bogomils, Paulicians, Bulgaria, Paulician legend of Rome, ritual of the baptism by fire.

Hristo Saldzhiev

Trakia University - Stara Zagora

Faculty of Education

Department of Pedagogical and Social Sciences

St. Armejska 9, Stara Zagora 6000, Bulgaria

Plovdiv University - Paisii Hilendarski

Faculty of Philology

Department of History of Bulgarian Language and Common Linguistic hristosaldzhiev@yahoo.com 